\title{
Suplementasi Ekstrak Asam Kandis (Garcinia xanthochymus) dalam Air Minum terhadap Kadar Malondialdehid Kuning Telur dan Komposisi Kimia Daging dan Telur Puyuh
}

\author{
Supplementation of Garcinia xanthochymus Extract on Water to Malondialdehid Content of Egg Yolk and Chemical \\ Composition of Quail Meat and Eggs \\ W U Cahyani, A Darmawan, D M Suci*
}

Corresponding email: dwi.margi2@gmail.com

Departemen Ilmu Nutrisi dan Teknologi Pakan Fakultas Peternakan IPB University, J. Agatis Kampus IPB Dramaga, Bogor, Indonesia

Submitted : $22^{\text {nd }}$ March 2021 Accepted : $30^{\text {th }}$ April 2021

\section{ABSTRACT}

The purpose of this study was to evaluate the effect of supplementation of Garcinia xanthochymus extract in drinking water on the quail meat and eggs quality (fat content, protein content) and malondialdehyde (MDA) on egg yolk. This study used female quails (132 tails) aged 42 days, which were kept for 6 weeks, and then divided into four groups treatments of drinking water, and 3 replications each treatment. The method used was a Completely Randomized Design (RAL) with P0 (control), P1 (pH 4), P2 (pH 3), P3 ( $\mathrm{pH} \mathrm{2).} \mathrm{The} \mathrm{variables} \mathrm{observed} \mathrm{were} \mathrm{moisture} \mathrm{content,} \mathrm{crude} \mathrm{fat} \mathrm{content} \mathrm{and}$ crude protein content in quail meat and eggs but MDA only on yolk eggs. The results showed a significantly decreased $(\mathrm{p}<0.05)$ effect of Garcinia xanthochymus extract supplementation in drinking water on MDA levels of quail eggs. However it had no significant effect on moisture content, crude fat content, and crude protein content in quail eggs and significantly increased crude protein in meat. It was concluded that giving extract of Garcinia Xanthochymus extract (kandis acid) at pH 2 in drinking water decreased the MDA content of quail egg yolks.

Key words: anti-oxidant, Garcinia Xanthochymus, chemical compound of meat and egg, egg yolk MDA

\section{ABSTRAK}

Tujuan penelitian ini untuk mengevaluasi pengaruh suplementasi ekstrak asam kandis (Garcinia xanthochymus) dalam air minum terhadap kualitas daging dan telur puyuh (kadar lemak, kadar protein) dan kadar malondialdehida (MDA) hanya pada kuning telur. Penelitian ini menggunakan puyuh betina sebanyak 132 ekor berumur 42 hari yang dipelihara selama 6 minggu, kemudian dibagi dalam empat kelompok perlakuan air minum dengan 3 ulangan pada setiap perlakuan. Rancangan Acak Lengkap (RAL) dengan perlakuan tingkat $\mathrm{pH}$ ekstrak asam kandis yang berbeda, yaitu P0 (kontrol), P1 ekstrak asam kandis dalam air minum dengan pH 4 (P1), pH 3(P2), pH 2 (P3) digunakan pada penelitian ini. Peubah yang diamati adalah kadar air, kadar lemak kasar dan kadar protein kasar pada daging dan telur puyuh serta MDA pada kuning telur. Hasil penelitian menunjukkan suplementasi ekstrak asam kandis dalam air minum nyata menurunkan $(\mathrm{p}<0,05)$ kadar MDA kuning telur puyuh, namun perlakuan tidak berpengaruh nyata terhadap kadar air, kadar lemak kasar, kadar protein kasar pada kuning telur. Kesimpulannya bahwa pemberian ekstrak asam kandis pada pH 2 dalam air minum menurunkan kandungan MDA pada kuning telur puyuh.

Kata kunci: antioksidan, asam kandis, Garcinia xanthochymus, komposisi kimia daging dan telur, MDA kuning telur 


\section{PENDAHULUAN}

Asam kandis (Garcinia diocia Blume), termasuk ke dalam tanaman genus Garcinia yang tersebar didaerah tropis Asia. Di Indonesia asam kandis banyak terdapat di Kalimantan, Sumatra, Jawa dan Bali (Heyne 1978). Asam kandis termasuk salah satu bumbu masak yang banyak digunakan pengganti asam Jawa. Nama asam kandis bermacam-macam seperti di Sumatra Barat disebut asam kandih, di Lampung disebut kunyi talerang, di Kalimanatan disebut buran. Selain itu di India disebut kokkam dan di Malaysia disebut asam gelugor/asam keeping. Buah asam kandis memiliki kandungan fraksi etil asetat yang mengandung senyawa golongan fenolik, flavonoid, alkaloid dan saponin, serta memiliki peran sebagai antioksidan (Tursiman et al. 2012). Selain itu asam kandis mengandung xanthan, flavonoid, isocoumarins, benzophenone dan dapat berperan sebagai antidiabetes, antioksidan, cytoxity dan antimikroba (Hassan et al. 2018; Hemshekhar et al. 2011). Senyawa antioksidan adalah inhibitor yang bekerja menghambat oksidasi dengan cara bereaksi dengan radikal bebas reaktif (Laguerre et al. 2007).

Adapun kandungan asam-asam organik yang terdapat pada Garcinia sp diantaranya asam hidroksi sitrat (hydroxyl citric acid/HCA) (Jena et al. 2002a \& b). HCA merupakan asam utama dalam buah Garcinia (Onakpoya et al. 2011). Penelitian Lucida et al. (2012), menyatakan bahwa kandungan zat aktif berupa HCA dapat menyebabkan $\mathrm{pH}$ dalam suatu larutan menjadi bersifat asam atau menyebabkan penurunan nilai $\mathrm{pH}$.

Penggunaan asam kandis sebagai feed additive untuk menurunkan stres oksidatif pada puyuh dapat digunakan karena mempunyai zat aktif sebagai sumber antioksidan yang dapat memperbaiki peforma puyuh. Penggunaan asam kandis sebagai feed additive dikombinasikan dengan mengatur $\mathrm{pH}$ air minum yang berfungsi sebagai acidifier yang dapat meningkatkan kesehatan puyuh dan berpengaruh terhadap kualitas daging dan telur yang dihasilkan.

Keadaan stres oksidatif biasanya terjadi bila jumlah radikal bebas lebih tinggi dibandingkan jumlah antioksidan dalam tubuh. Stres oksidatif tubuh dapat ditentukan dengan mengukur salah satu variabelnya, yaitu kadar malondialdehid (MDA) dalam plasma. Semakin tinggi kadar MDA plasma maka semakin tinggi stres oksidatif yang terjadi dalam sel-sel tubuh (Valko 2006). MDA dapat terbentuk apabila radikal bebas hidroksil seperti reactive oxygen species (ROS) bereaksi dengan komponen asam lemak dari membran sel sehingga terjadi reaksi berantai yang dikenal dengan peroksidasi lemak.. Suatu radikal bebas cenderung terlebih dahulu akan bereaksi dengan antioksidan dibandingkan dengan molekul yang lain (Juswono et al. 2013).
Aktivitas antioksidan yang pada telur dapat di duga salah satunya dengan mengukur kadar Malondialdehid (MDA) (Sahin et al. 2008). Antioksidan ini sendiri terdapat pada bagian kuning telur (Gaffney et al. 2015). Antioksidan mampu menghambat radikal bebas dan mengubahnya menjadi senyawa non radikal. Oleh karena itu, penelitian ini dilakukan untuk mengukur kadar MDA kuning telur sebagai indikator radikal bebas yang menyerang tubuh ternak dan aktivitas antioksidan. Penelitian ini bertujuan untuk mengetahui suplementasi ekstrak asam kandis (Garcinia xanthochymus) dalam air minum terhadap kualitas daging dan telur puyuh (kadar lemak, kadar protein, malondialdehid).

\section{METODE}

\section{Ternak dan Kandang}

Puyuh betina (Coturnix-coturnix japonica) yang digunakan pada penelitian ini sebanyak 132 puyuh betina yang berumur 42 hari dipelihara selama 6 minggu, kemudian dibagi dalam 4 perlakuan dengan 3 ulangan secara acak. Puyuh dipelihara pada kandang koloni yang dibagi 12 petak yang berisi 11 ekor. Setiap petak kandang dilengkapi tempat ransum dan tempat air minum

\section{Ransum}

Ransum komersial layer diberikan ke puyuh menagndung protein $20,71 \%$. Kandungan nutrien ransum komersial disajikan pada Tabel 1.

\section{Pembuatan Ekstrak Buah Asam Kandis}

Buah asam kandis kering ditimbang sebanyak 40 gram dimasukan ke dalam 1 liter air yang telah mendidih selama 60 menit kemudian didiamkan selama satu malam yang digunakan sebagai biang ekstrak asam kandis. Biang yang telah terbentuk kemudian diambil sebanyak 1 liter dan di tambahkan 1,5 liter air untuk membuat larutan dengan $\mathrm{pH}$ 2. Pembuatan larutan $\mathrm{pH} 3$ yaitu dengan cara 1 liter biang asam kandis ditambahkan dengan 4 liter air. Pembuatan larutan $\mathrm{pH} 4$ yaitu dengan cara 1 liter biang asam kandis ditambahkan dengan 23 liter air. Pengecekan $\mathrm{pH}$ pada setiap larutan perlakuan menggunakan kertas lakmus.

Tabel 1 Kandungan nutrien ransum puyuh periode layer

\begin{tabular}{lc}
\hline Analisa Proksimat & Hasil (\%) \\
\hline Kadar Air (\%) & 8,88 \\
Protein (\%) & 20,71 \\
Lemak (\%) & 5,54 \\
Serat Kasar (\%) & 2,24 \\
Abu (\%) & 14,27 \\
\hline
\end{tabular}

Hasil Analisis Pusat Penelitian Sumberdaya Hayati dan Bioteknologi, Fakultas Teknologi Pertanian, Institut Pertanian Bogor. 


\section{Pemeliharaan Puyuh}

Pemberian ransum sebanyak 25 g ekor $^{-1}$ hari $^{-1}$. Sisa ransum ditimbang setiap minggu. Pemberian ekstrak asam kandis dilakukan 2 (dua) hari berturut-turut per minggu selama pemeliharaan. Perlakuan tersebut dilakukan selama 6 minggu masa pemeliharaan. Ransum yang digunakan adalah ransum komersial puyuh layer. Setiap burung puyuh mendapatkan 90,9 ml air minum dengan penambahan ekstrak buah asam kandis. Pengukuran konsumsi air minum dilakukan setiap hari. Pada akhir penelitian diambil sebanyak 12 ekor puyuh yang digunakan untuk sampel pengukuran kualitas daging dada dan 60 sampel kuning telur puyuh dianalisis kadar lemak, kadar protein, dan MDA dan masing masing ulangan 5 buah kuning telur.

\section{Peubah}

\section{Pengukuran Kadar Air Daging dan Telur}

Pengukuran kadar air menggunakan metode Sudarmadji et al. (2007). Cawan porselin yang sudah diberi kode sesuai sampel dipanaskan dalam oven dengan suhu 100$105^{\circ} \mathrm{C}$ selama \pm 1 jam, cawan porselin diambil, dimasukkan ke dalam desikator \pm 15 menit kemudian cawan porselin ditimbang. Sampel daging dan telur ditimbang sebanyak $20 \mathrm{~g}$ dalam cawan porselin yang sudah diketahui beratnya. Sampel dikeringkan dalam oven pada suhu $100-105^{\circ} \mathrm{C}$ selama $4-5$ jam. Setelah sampel dioven, kemudian sampel diambil dan dimasukkan di dalam desikator \pm 15 menit, dilanjutkan dengan penimbangan. Pengeringan sampai diperoleh berat konstan.

Rumus kadar air $=$

$\frac{(\text { b. cawan }+ \text { b. sampel })-(\text { b. cawan }+ \text { b. sampel setelah dioven })}{\text { berat bersih }} \times 100 \%$

\section{Pengukuran Kadar Protein Daging dan Telur}

Pengukuran kadar protein menggunakan adalah metode Kjeldahl (AOAC 1980)). Sampel ditimbang sebanyak 0,5 g, kemudian ditambahkan 0,5 g katalis selenium mixture. Kemudian dimasukkan ke dalam labu Kjeldahl dan ditambahkan $10 \mathrm{~mL} \mathrm{H2SO4} \mathrm{pekat.} \mathrm{Destruksi} \mathrm{dilakukan}$ sampai warna larutan menjadi cairan jernih, lalu didinginkan. Setelah itu ditambahkan $\mathrm{NaOH}$ dan asam standar asam borat (H3BO4) 4\% sebanyak $20 \mathrm{ml}$, serta ditambahkan metylen red (MR) dan metylen blue (MB) sebanyak 2 tetes, lalu dilakukan destilasi. Hasil destilasi ditampung dan ditambah $50 \mathrm{ml}$ aquades dan $40 \mathrm{ml}$ natrium hidroksida $(\mathrm{NaOH}) 45 \%$, sampai terjadi perubahan warna dari ungu menjadi biru-kehijauan. Proses tirasi menggunakan asam khorida ( $\mathrm{HCl}$ ) 0,1 N, sampai terjadi perubahan warna larutan dari hijau menjadi ungu.

Kadar protein dihitung dengan rumus:

$\% \mathrm{~N}=\frac{\mathrm{ml} \mathrm{HCl}-\mathrm{ml} \text { Blangko } \times \text { Normalitas } \mathrm{HCl} \times 14,007 \times 100}{\mathrm{mg} \text { sampel }} \times 100 \%$

\section{Keterangan :}

$\begin{array}{ll}\text { ml blangko } & : 0,1 \mathrm{ml} \\ \mathrm{N} \mathrm{HCl} & : 0,043664 \\ \text { \% Protein Total } & : \% \mathrm{~N} \mathrm{x} \mathrm{6,25 \%}\end{array}$

\section{Pengukuran Kadar Lemak Daging dan Telur}

Pengukuran kadar lemak menggunakan metode Soxhlet (AOAC 1984). Selongsong dimasukkan ke dalam alat soxhlet \pm 2 jam dan labu lemak yang telah diketahui bobotnya di pasang pada alat soxhlet. $50 \mathrm{~mL}$ hexane dimasukkan ke dalam alat soxhlet. Sampel di ekstrak dengan pelarut hexana. Labu lemak dikeringkan dalam oven $105^{\circ} \mathrm{C}$ selama 30 menit, hingga aroma hexana tidak tercium. Labu didinginkan dalam desikator selama 15 menit. Labu lemak ditimbang.

Kadar lemak dihitung dengan rumus= $\frac{\text { berat labu akhir }(\mathrm{g}) \text {-berat labu awal }(\mathrm{g})}{\text { berat sampel }(\mathrm{g})} \times 100 \%$

\section{Uji Kadar Malondialdehid (MDA) Kuning Telur}

Metode TBARs yang dimodifikasi oleh Singh et al. (2002) digunakan untuk mengukur MDA. Langkah pertama adalah menyiapkan sampel terlebih dahulu. Sampel kuning telur dikeluarkan dari freezer dan dicairkan. Kuning telur ditimbang sebanyak $5 \mathrm{~g}$ per sampel menggunakan timbangan analitik. Setelah itu sampel disimpan kembali di dalam freezer untuk selanjutnya digunakan saat pengukuran MDA. Langkah kedua yaitu menyiapkan larutan PBS-KCl dengan menggunakan bahan 0,0243g KH2PO4, 0,0203g KCl, 0,144g Na2HPO4, $0,8 \mathrm{~g} \mathrm{NaCl}$. Pembuatan larutan reagen, dengan bahanbahan yang digunakan adalah $\mathrm{HCl} 0,25 \mathrm{~N}$ yang mengandung 10g TCA, 0,38g TBA, dan 0,5g BHT, dan 2,23ml $\mathrm{HCl}$ pekat. Langkah ketiga yaitu telur yang telah diukur dan siap untuk dianalisa kadar MDA dimasukkan dalam gelas piala dan ditambahkan $2 \mathrm{ml}$ PBS-KCL dingin, diaduk hingga rata dengan stirer. Sampel dioven terlebih dahulu, disentrifuge selama 20 menit dengan kecepatan $10.000 \mathrm{rpm}$. Supernatan yang terbentuk dimasukkan dalam tabung ependorf dan siap dengan $2 \mathrm{ml}$ uji MDA. Langkah keempat yaitu supernatan diambil 0,5 ml ditambahkan dengan 2 ml larutan campuran (larutan campuran terdiri dari 2,23 ml HCl pekat, $10 \mathrm{~g}$ TCA, 0,38 g TBA, 0,5g BHT dalam $100 \mathrm{ml}$ aquades) dan dihomogenkan. Kemudian dipanaskan selama 30 menit menggunakan oven. Setelah 1 jam diangkat dan didinginkan dalam suhu ruangan. Sentrifuge dilakukan selama 5 menit dengan kecepatan 3500 rpm. Supernatan dituang pada tabung lain untuk dibaca absorbansinya pada alat spektrofotometer dengan panjang gelombang $540 \mathrm{~nm}$ diukur dengan memasukkan nilai absorban pada persamaan regresi dan diperoleh dalam satuan $\mu$ mol. Hasil regresi kemudian digunakan untuk menentukan konsentrasi MDA dalam satuan $\mu$ mol. Konsentrasi MDA diperoleh dari pengukuran OD sampel yang telah dikoreksi dengan standar TEP dan dimasukkan kedalam 
persamaan regresi. Selanjutnya dikonversi menjadi konsentrasi ppm $(\mathrm{mg} / \mathrm{kg})$ dengan mengalikan konsentrasi MDA, bobot sampel, dan pengenceran ekstraksi TBA, sehingga didapat konsentrasi MDA dalam satuan $\mathrm{mg} / \mathrm{kg}$.

Kadar MDA dihitung dengan rumus :

$\operatorname{MDA}\left(\mathrm{mg} \mathrm{kg}^{-1}\right)=\frac{\text { A } \times \text { PM MDA } \times \text { V x TBA }}{\text { BB } \times \text { KS } \times 1000}$

$\begin{array}{ll}\text { A } & \text { : Absorbansi sampel } \\ \text { PM MDA } & \text { : Kadar MDA yang diperoleh dari persamaan regresi } \\ & \text { kurva standar } \\ \text { V } & \text { : Volume ekstraksi } \\ \text { TBA } & \text { : Pengenceran ekstraksi TBA } \\ \text { BB } & \text { : Bobot sampel } \\ \text { KS } & \text { : Kurva standar }\end{array}$

\section{Rancangan Percobaan dan Analisis Data}

Penelitian ini menggunakan Rancangan Acak Lengkap dengan 4 perlakuan dan 3 ulangan. Perlakuan yaitu tingkat pemberian ekstrak buah asam kandis dalam air minum dengan $\mathrm{pH} 4$ (P1), $\mathrm{pH} 3$ (P2) dan $\mathrm{pH} 2$ (P3) dan air minum tanpa ekstrak sebagai kontrol (PO).

Data yang diperoleh dianalisis sidik ragam untuk mengetahui pengaruh perlakuan terhadap peubah yang diamati. Jika peubah nyata dilanjutkan dengan uji LSD untuk menentukan nyata antara nilai rata rata.

\section{HASIL DAN PEMBAHASAN}

\section{Kadar Malondialdehida (MDA) pada Kuning Telur Puyuh}

Tingkat suplementasi ekstrak asam kandis dalam air minum berpengaruh nyata $(\mathrm{p}<0,05)$ terhadap kadar Malondialdehid kuning telur puyuh. Pada Tabel 2 menunjukkan nilai MDA pada kuning telur puyuh yang diberi ekstrak asam kandis dengan $\mathrm{pH} 2$ pada air minum nyata lebih rendah dari perlakuan lain. Hasbullah et al.(2020) menyatakan bahwa pemberian jus daun afrika pada air minum puyuh juga menurunkan kadar MDA kuning telur.

Pada P3 (pemberian ekstrak asam kandis dengan pH 2) diperoleh penurunan yang nyata kadar MDA. Kandungan pH yang rendah tersebut disebabkan adanya kandungan asam-asam organik yang lebih tinggi dalam air minum diantaranya asam hidroksi sitrat (Jena et al. 2002a \& b) yang mempunyai aktivitas antioksidan yang tinggi.

Tabel 2 Pengaruh suplementasi ekstrak buah asam kandis terhadap kadar MDA pada kuning telur puyuh

\begin{tabular}{lc}
\hline Perlakuan/pH air minum & $\mathrm{MDA}\left(\mathrm{mg} \mathrm{kg}^{-1}\right)$ \\
\hline P0(kontrol) & $0,54 \pm 0,12^{\mathrm{a}}$ \\
P1 (pH 4) & $0,53 \pm 0,14^{\mathrm{a}}$ \\
P2 (pH 3) & $0,60 \pm 0,02^{\mathrm{a}}$ \\
P3 (pH 2) & $0,39 \pm 0,06^{\mathrm{b}}$ \\
\hline
\end{tabular}

MDA : malondialdehida, a dan b superskrip yang berbeda pada kolom yang sama menunjukkan perbedaan nyata $(\mathrm{p}<0,05)$
Aktivitas antioksidan fraksi etil asetat buah asam kandis memiliki nilai IC50 sebesar 37,833 ppm, semakin kecil nilai IC50 maka berpengaruh pada aktivitas dalam menangkal senyawa radikal bebas akan semakin tinggi (Hidayat et al. 2018). Lucida et al. (2012), menyatakan bahwa kandungan zat aktif berupa HCA dapat menyebabkan $\mathrm{pH}$ dalam suatu larutan menjadi bersifat asam. Hal ini menandakan bahwa, semakin tinggi kadar antioksidan yang terkandung maka akan semakin menurunkan kadar MDA. Nilai MDA pada telur berkorelasi terhadap aktivitas antioksidan, semakin tinggi kadar MDA maka berkorelasi terhadap rendahnya antivitas antioksidan (Liou \& Storz 2010).

Buah asam kandis diketahui memiliki kandungan fraksi etil asetat yang mengandung senyawa golongan fenolik, flavonoid, alkaloid dan saponin, serta memiliki peran sebagai antioksidan untuk menangkal radikal bebas (Tursiman et al. 2012. Senyawa fenolik merupakan senyawa metabolit sekunder yang banyak ditemukan pada tumbuhan, yang memiliki kemampuan menghambat kerja radikal bebas (Duenas et al. 2009). Aktivitas antioksidan berbanding lurus dengan total fenol, semakin tinggi kandungan fenol dalam suatu bahan semakin tinggi pula aktivitasnya sebagai antioksidan (Huang et al. 2005).

\section{Kualitas Daging Dada dan Kuning Telur Puyuh Kadar Air}

Tingkat suplemen asam kandis dalam air minum tidak berpengaruh terhadap kadar air daging dada dan kuning telur puyuh (Tabel 3) dengan rata-rata persentase kadar

Tabel 3 Pengaruh suplemen ekstrak buah asam kandis terhadap kualitas daging dada dan kuning telur puyuh

\begin{tabular}{|c|c|c|c|c|}
\hline \multirow{2}{*}{ Paramater } & \multicolumn{4}{|c|}{ Perlakuan } \\
\hline & $\mathrm{PO}$ & P1 & $\mathrm{P} 2$ & P3 \\
\hline \multicolumn{5}{|l|}{ Kuning telur } \\
\hline $\begin{array}{l}\text { Kadar air } \\
(\%)\end{array}$ & $47,30 \pm 0,79$ & $46,82 \pm 0,58$ & $47,50 \pm 0,94$ & $47,08 \pm 0,77$ \\
\hline $\begin{array}{l}\text { Kadar } \\
\text { lemak (\%) }\end{array}$ & $22,98 \pm 1,63$ & $23,58 \pm 2,35$ & $23,51 \pm 0,28$ & $25,02 \pm 1,18$ \\
\hline $\begin{array}{l}\text { Kadar } \\
\text { Protein \%) }\end{array}$ & $14,99 \pm 0,83$ & $14,69 \pm 0,15$ & $14,48 \pm 0,37$ & $15,45 \pm 0,53$ \\
\hline
\end{tabular}

\begin{tabular}{|c|c|c|c|c|}
\hline \multicolumn{5}{|c|}{ Daging dada } \\
\hline $\begin{array}{l}\text { Kadar air } \\
\text { (\%) }\end{array}$ & $72,15 \pm 1,80$ & $73,38 \pm 2,22$ & $72,36 \pm 0,16$ & $72,48 \pm 1,42$ \\
\hline $\begin{array}{l}\text { Kadar } \\
\text { lemak (\%) }\end{array}$ & $0,96 \pm 0,02$ & $0,97 \pm 0,09$ & $0,98 \pm 0,27$ & $0,88 \pm 0,16$ \\
\hline $\begin{array}{l}\text { Kadar } \\
\text { Protein (\%) }\end{array}$ & $3,14 \pm 0,63^{b}$ & $22,38 \pm 0,88^{b}$ & $23,01 \pm 0,41^{b}$ & $24,45 \pm 0,32^{a}$ \\
\hline \multicolumn{5}{|c|}{$\begin{array}{l}\text { P0 (air minum tanpa penambahan ekstrak buah asam kandis), P1 } \\
\text { (Air minum + ekstrak buah asam kandis dengan pH 4), P2 (Air } \\
\text { minum + ekstrak buah asam kandis dengan pH 3), P3 (Air minum + } \\
\text { ekstrak buah asam kandis dengan pH 2). Superskrip yang berbeda } \\
\text { pada kolom yang sama menunjukkan perbedaan nyata }(\mathrm{p}<0,05)\end{array}$} \\
\hline
\end{tabular}


air pada daging dada puyuh yaitu 72,15-73,38\%, dan pada kuning telur yaitu 46,82-47,50\%. Kadar air kuning telur tidak dipengaruhi oleh adanya zat biokatif yang terdapat pada perlakuan. Kadar air kuning telur ini seuai dengan hasil penelitian Hasbullah et al. 2020, Tolik et al. (2014) dan Song et al. 2000 berkisar 48,7- 49,7 \%. Kadar air dalam daging puyuh sangat dipengaruhi oleh umur puyuh terlihat dari hasil penelitian Genchev et al. (2008) pada umur 35 hari sebesar 73,08\%. dan Raji et al. (2015) umur 13 minggu sebesar 80,43\%. Suplemen asam kandis sebagai acidifier dalam air minum dapat mengendalikan mikroorganisme yang tidak diinginkan dengan menurunkan $\mathrm{pH}$ di saluran pencernaan karena adanya asam hidroxi sitrat (HCA) (Lucida et al. 2012). $\mathrm{pH}$ air minum untuk ternak yang normal mempunyai $\mathrm{pH}$ 6,87,5. Pada $\mathrm{pH}$ air minum yang lebih rendah ada kemungkinan konsumsi air minum akan turun, tetapi pada penelitian ini tidak terlihat penurunan konsumsi air minum karena pemberian hanya dua kali dalam seminggu dan terlihat juga dari kadar air pada daging dada dan kuning telur tidak dipengaruhi oleh perlakuan.

\section{Kadar Lemak}

Tingkat suplemen asam kandis yang diberikan dalam air minum tidak berpengaruh terhadap kadar lemak daging dada dan kuning telur puyuh (Tabel 3). Hasil penelitian diperoleh rata-rata persentase kadar lemak pada daging dada puyuh yaitu $0,88-0,98 \%$, sedangkan pada kuning telur yaitu 22,98-25,02\%. Persentase kadar lemak kuning telur pada penelitian ini lebih rendah dari Hasbullah et al. (202) sebesar 27-28\%. Kadar lemak kuning telur menurut Tolik et al. (2014) sebesar 31,5\% sedangkan Song et al. (2000) sebesar 31,48 \%. Genchev et al. (2008) melaporkan bahwa kandungan lemak daging dada puyuh berumur 35 hari sebesar 2,75\% dan Raji et al. (2015) puyh berumur 12 minggu sebesar 1,17\%. Penambahan ekstrak asam kandis yang semakin banyak menyebabkan $\mathrm{pH}$ air minum perlakuan mulai $\mathrm{pH}$ 2 sampai pH 4 tidak mempengaruhi kadar lemak daging dan telur puyuh. Pada penelitian ini tidak terjadi perubahan metabolisme lemak yang disebabkan oleh adanya HCA.

Kandungan asam-asam organik secara kompetitif berperan penting dalam metabolisme lemak (lypogenesis) (Jena et al. 2002a \& b). Asam hidroksi sitrat sendiri dapat menekan sintesa asam lemak dan lipogenesis pada hewan ternak (Jena et al. 2002a), tetapi pada penelitian ini tidak kelihatan peranan asam asam organik pada ekstrak asam kandis untuk menurunkan kadar lemak pada daging dan kuning telur.

\section{Kadar Protein}

Hasil penelitian menunjukkan bahwa pemberian asam kandis pada air minum tidak mempengaruhi kadar protein telur tetapi pada air minum $\mathrm{pH} 2$ nyata $(\mathrm{p}<0,05)$ meningkatkan kadar protein daging. Hasil penelitian diperoleh rata-rata persentase kadar protein kasar pada daging dada puyuh yaitu 23,14 \% - 24,45 \%, sedangkan pada kuning telur yaitu 14,99\% - 15,45\%. Kadar protein kuning telur puyuh hasl penelitian sama dengan yang dilaporkan oleh Hasbullah et al. (2020). Tolik et al. (2014) menyatakan bahwa kadar protein pada kuning telur puyuh jepang $16 \%$, sedangkan Song et al. 2000 $15,99 \%$. Genchev et al. (2008), puyuh berumur 35 hari sebesar 22.23\% dan Raji et al. (2015) puyuh berumur 12 minggu yaitu $17.84 \%$. Perlakuan pemberian ekstrak asam kandis P1 (pH 4) dan P2 (pH 3) menunjukkan kadar protein yang tidak berbeda dengan kontrol tetapi pada P3 (pH2) lebih tinggi (PK 24,45\%). Hasbullah et al. (2020), menyatakan bahwa pemberian bioaktif yang terkandung pada jus daun afrika dalam air minum tidak nyata mempengaruhi kadar protein kuning telur. Pada air minum $\mathrm{pH} 2$ lebih banyak mengandung asam hidroksi sitrat sebagai antioksidan sehingga ayam tidak mengalami stress terlihat dari kadar MDA yang paling rendah. Asam hidroksi sitrat yang lebih tinggi pada $\mathrm{pH}$ air minum 2 di duga konsentrasi bakteri patogen menurun. Keadaan ini menyebabkan pertumbuhan otot lebih baik yang menghasilkan kadar protein lebih tinggi. Sesuai dengan pendapat Emma et al. (2013) bahwa kandungan asam organik akan menurunkan bakteri patogen dalam usus sehingga kecernaan protein maupun karbohidrat lebih optimum.

\section{SIMPULAN}

Pemberian asam kandis dalam air minum pada $\mathrm{pH} 2-4$ menghasilkan komposisi kimia yang sama pada kuning telur, tetapi pada pH 2 meningkatkan kadar protein daging dibandingkan kontrol. Kadar MDA pada air minum yang diberi asam kandis sampai $\mathrm{pH} 2$ menghasilkan MDA yang paling rendah..

\section{DAFTAR PUSTAKA}

Duenas M, Manzano SO, Paramas AG, \& Buelga SC. 2009. Antioxidant evaluation of o-methylated metabolites of catechins, epicatechin, and quersetin. Journal of Pharmaceutical and Biomedical Analysis. 51(2):443-449. DOI:10.1016/j.jpba.2009.04.007

Emma WMSM, Sjofjan O, Widodo E \& Achmanu. 2013. Karakteristik usus halus ayam pedaging yang diberikan asam jeruk nipis dalam pakan. Jurnal Veteriner. 14(1):105-110

Gaffney M, O' RR, Taylor PJ \& Murphy R. 2015. A comparative assessment of the fatty acid profiles and antioxidant status of supermarket eggs. Journal of Applied Animal Nutrition. 1(5):112115. DOI:10.1017/jan.2015.7

Genchev A, Mihaylova G, Ribarski S, Pavlov A \& Kabakchiev M. 2008. Meat quality and composition in japanese quails. Trakia Journal of Sciences. 6(4):72-82.

Hasbullah I, Wulandari Z \& Suci DM. 2018. Suplemen jus daun Afrika (Vernonia amygdalina) dalam air minum terhadap komposisi kimia dan kadar Malondialdehid telur puyuh (Coturnix coturnix japonica). Jurnal Ilmu Nutrisi dan Teknologi Pakan, 18 (2): 11-18 
Hassan, NKNC, Taher,M \& Susanti D. 2018. Phytochemical constituents and pharmacological properties of Garcinia xanthochymus- Review Biomedicine \& Pharmacotherapy 106: 1378 - 1389

Hemshekhar, M, Sunitha K, Santhosh MS, Devaraja S, Kemparaju K, Vishwanath BS, Niranjana SR \& Girish KS. 2011. An overview on genus garcinia: phytochemical and therapeutical aspects. Phytochemistry Reviews. 10: 325-351

Heyne K.1987. Tumbuhan Berguna Indonesia. Jilid III. Terjemahan, Jakarta (ID): Badan Litbang KehutananYayasan Sarana Wana Jaya

Hidayat WA, Ardinigsih P\& Jayuska A. 2018. Aktivitas antioksidan dan antibakteri fraksi etil asetat buah asam kandis (garcinia dioica blume) terenkapsulasi gelatin. Jurnal Kimia Khatulistiwa. 7(2):3340.

Huang C. 2005. Identification of an antifungal chitinase from a potential biocontrol agent, Bacillus cereus. Journal of Biochemistry and Molecular Biology. 38(1):82-88.

Jena BS, Jayaprakasha GK, Singh RP \& Sakariah KK. 2002a. Chemistry and biochemistry of hydrocitric acid from garcinia. Journal of Agricultural Food Chemistry. 50 (1) :10-22.

Jena BS, Jayaprakasha GK \& Sakariah KK. 2002b. Organic acid from leaves, fruit and rinds of Garcinia Cowa. Journal of Agricultural Food chemistry. 50(12):3431-3434.

Laguerre M, Lecomte J. \& Villeneuve P. 2007. Evaluation of the abilty oof antioxidants to counteract lipid oxidation: existing methods, new trends and challenges. Progress in Lipid Research. 4695): 244-282

Lucida H, Ben ES \& Delita E. 2012. Pengembangan kulit buah kering asam kandis sebagai herbal medicine: optimasi formulasi tablet effervesen dan uji efeknya terhadap kenaikan berat badan dan pola makan tikus. Jurnal Sains dan Teknologi Farmasi. 17(2):126-136.

Raji AO, Girgiri AY, Alade K, \& Jaure SA. 2015.Characteristics and proximate composition of japanese quail (coturnix japonica) carcass in a semi arid area of Nigeria.Trakia Journal of Science. 2:159-165

Sahin N, Akdemir F, Orhan C, Kucuk O, Hayirli A \& Sahin K. 2008 Lycopene-enriched quail egg as functional food for humans. Food Research International. 41(3):295-300.

Singh,RP, Murthy KNC,Jayaprakasha GK. 2002. Studies on the antioksidant activity of pomegranate (Punica grantum) peel and seed extracts using in vitro models. Journal of Agricultural and Food Chemical 50 (1): 81-86

Song, KT, Chei SH,\& Oh HR. 2000. A Comparison of egg Quality of pheasant, chukar, quail and guinea fowl . Asian-Australasian Journal of Animal Science 13(7) : 986-990

Sudarmadji S, Haryono SB \& Suhardi.2007. Analisis Bahan Makanan dan Pertanian .Yogyakarta (ID) : Liberty

Tolik D. Poawska E, Charuta A, Nowazewski S \& Cooper R. 2014. Characteristics of egg parts, chemical composition and nutritive value of Japanese quail eggs-a Review. Folia Biologica (Krakow) 62(4): 287-292

Tursiman, Ardiningsih P, \& Nofiani R. 2012. Total fenol fraksi etil asetat dari buah asam kandis (Garcinia Diocia Blume). Jurnal Kimia Khatulistiwa. 1:45-48

Valko M, Rhodes CJ, Moncola J, Izakovic M \& Mazur M. 2006. Free radicals, metals and antioxidants in oxidative stress-induced cancer. Chemico-Biological Interactions. 160(1): 1-40. 